Davor Labaš

Marina Rajsman ${ }^{* *}$
JEL klasifikacija: M00, M21. Prethodno priopćenje

https://doi.org/10.32910/ep.71.3.3

\title{
ISTRAŽIVANJE ULOGE I PERSPEKTIVE RAZVOJA KONTROLERA KAO POSLOVNOG PARTNERA MENADŽMENTA
}

Megatrendovi poput rastuće kompleksnosti i volatilnosti poslovnog okruženja, internacionalizacije i sve veće potrebe za transparentnosti uzrokovale su promjene očekivanja menadžmenta spram kontrolera, a time $i$ nove uloge. Brojna istraživanja naglašavaju i usmjeravaju te promjene ka sve aktivnijoj ulozi kontrolera kao ravnopravnom partneru menadžmentu u procesu odlučivanja na strateškoj razini poduzeća, uz istovremeni sve veći razvoj digitializacije i IT rješenja koji će omogućiti stvaranje dodane vrijednosti i oslobađanje kontrolera od rutinskih zadataka i time stvoriti prostor za novu ulogu. Dosada je nedovoljno istraženo kolika se ta nova uloga u praksi zaista provodi i koje su posljedice kontrolera kao poslovnog partnera menadžeru s kojim bi istovremeno trebao surađivati $i$ korigirati njegove radnje. $U$ ovom radu istražuje se perspektiva u razvoju kontrolera kao poslovnog partnera, i u svrhu toga provedeno je empirijsko istraživanje uloga kontrolera (eng. controller, odnosno management accountant) u poduzećima na području Republike Hrvatske istražujući koje uloge pretežno preuzimaju $i$ kreću li se ka proaktivnijoj budućnosti.

Ključne riječi: poslovni partner menadžmentu, nove uloge kontrolera, redefiniranje uloga kontrolera, razvoj digitalizacije i IT rješenja

* D. Labaš, dr. sc., Docent, Sveučilište u Zagrebu, Ekonomski fakultet Zagreb (e-mail: dlabas@ efzg.hr)

** M. Rajsman, mag.oec. Sveučilište u Zagrebu, Ekonomski fakultet Zagreb (e-mail: mrajsman@ gmail.com). Rad je primljen u uredništvo 21.03.2019. godine, a prihvaćen je za objavu 15.04.2019. godine. 


\section{Uvod}

Kontroling je tehnologija upravljanja na osnovi ekonomske logike racionalnosti, skup vještina koje su potrebne kako bi se na bazi mnoštva podataka iz okruženja poduzeća prikupio optimalan broj informacija koje su menadžerima neophodne za kvalitetno odlučivanje. Bez te informacijske potpore, menadžeri bi donosili odluke na temelju intuicije ili bi se oslanjali na analize drugih funkcija kao što su proizvodnja ili ostale poslovno razvojne funkcije (Laval, 2015, str. 54). Kontroling, dakle, karakterizira 3 glavna svojstva: cilju orijentirana kontrola, suradnja kontrolera i menadžera kao tima te međusobno djelovanje analitike i ,soft“ faktora organizacije (Schäffer, Losbichler, Gaensslen i Rieder, 2013, str. 311)1. Uvjeti poslovanja se neprekidno mijenjaju, a promjene traže sve brže reakcije i pronalaženje novih razvojnih pravaca. Istovremeno, dolazi do razvoja novih svojstava, novog načina funkcioniranja unutar dijelova ali i među dijelovima poduzeća što za posljedicu, a kao fokus ovog rada, ima razvoj nove uloge i zadataka kontrolera ${ }^{2}$.

Od danas potrebnih vještina, istraživanja pokazuju da se od kontrolera sve više očekuje strateško predviđanje i temeljitija, strateška analiza izvještaja (Lawson, 2016, str. 26). Istraživanje provedeno na 800 kontrolera u SAD-u pokazuje da kontroleri koji provode 60-74 \% vremena u tradicionalnoj ulozi ${ }^{3}$ ističu planiranje, budžetiranje, predviđanje kao najvažnije vještine, dok kontroleri koji troše 0-59\% vremena na tradicionalnu ulogu ističu analizu odluka (eng. decision analysis), znanje o industriji, statističko modeliranje/,,data analysis“ i životnu vrijednost korisnika $^{4}$ (eng. customer lifetime value) kao najpotrebnije vještine. Kao najvažnije „,soft vještine“ naglašavaju se strateško razmišljanje i implementacija, znanje o procesima i transformaciji te komunikacijske vještine (Waelter, Kaplan, Gibson, Krumwiede, 2018, str. 5-7).

Kontroleri budućnosti će trebati razviti 4 glavne vještine potrebne za uspjeh: vođenje, socijalna inteligencija, razvitak svijesti o poslovnom okruženju (eng.

${ }^{1}$ „Soft“ faktori organizacije se odnose na elemente koji postoje zbog prisutnosti ljudi u organizaciji kao npr. organizacijska kultura, menadžerski stil vođenja, ljudi i kvalifikacije, neformalni odnosi, timski rad, socijalna interakcija i zajedničke vrijednosti.

${ }^{2} \mathrm{U}$ ovom radu termini poslovni partner i business partner(ing) koriste se istovjetno, $\mathrm{s}$ istim sadržajem i opsegom.

${ }^{3}$ Pod tradicionalnom ulogom misli se na uloge nadzornika (eng. Steward) i operatera (eng. Operater) koje će u nastavku biti detaljnije objašnjene, a koje uključuju planiranje i rješavanje svakodnevnih zadataka.

${ }^{4}$ Customer Lifetime Value ili CLTV predstavlja ukupan iznos novca za koji se očekuje da će određeni korisnik potrošiti u poslovanju ili na proizvodima poduzeća tijekom njegova života. Ovo je bitan podatak budući da pomaže u donošenju odluka o tome koliko se treba investirati u akviziciju novih kupaca i zadržavanje postojećih. 
commercial awareness ${ }^{5}$ ) i preuzimanje inicijative (Gupta, Copleston, Malhotra, 2016, str. 2).

Današnje organizacije su pod pritiskom IT promjena, zahtjeva za inovativnošću, visokom konkurencijom (Byrne, Pierce, 2007, str. 469-470). Glavna konkurencija kontrolingu su eksterne konzultantske kompanije i in-house konzultanti koji se svi bave strateški orijentiranim aspektima istovjetnim poslu kontrolera (Laval, 2015, str. 61). Stoga, visoko kompetitivan svijet zahtijeva nove poslovne pristupe koji će omogućiti kontrolerima da brzo odgovore na promjene u okruženju. Uloga kontrolera postaje multidiomenzionalna kombinirajući više različitih aspekata praveći put ka novim razvojnim perspektivama.

Koliko novi poslovni pristupi mijenjaju kontroling u njegovoj prirodi i koliko je u stvarnosti primjenjiv u suradnji kontrolera i menadžera, otvoreno je za debatu te je stoga cilj ovoga rada istražiti implikacije modela kontrolera kao poslovnog partnera. Također, uz navedeni trend razvoja uloge kontrolera postoji potreba prikaza uloga i razvoja kontrolinga u Hrvatskoj, kao i razumijevanjem sadašnjih potreba poduzeća za kontrolerima.

Nadalje, provedena istraživanja te postojeća literatura zasada pružaju nepotpunu i kontradiktornu sliku suvremenih uloga kontrolera u pogledu nedovoljno istraženih posljedica. Ovaj rad stoga nastoji upotpuniti sliku razvoja kontrolera kao poslovnog partnera kao sljedeće generacije kontrolera te istražiti koliko su ispunjeni uvjeti u hrvatskim poduzećima za razvoj tako proaktivne uloge kontrolera i pružiti preporuke za daljnji razvoj.

Ostatak rada strukturiran je na sljedeći način. Pregled literature sadrži dosad znanu kategorizaciju uloga kontrolera na koju se nastavlja konceptualizacija business partneringa uključujući doprinos kontrolera kao poslovnog partnera i njegovo provođenje u praksi. Nakon toga su prezentirani istraživački ciljevi rada koji se baziraju na empirijskom istraživanju uvjeta za razvoj kontrolera kao poslovnog partnera u hrvatskim poduzećima kroz ispitivanje postojećeg stanja kompetencija, uloga i stupnja slobode kontrolera. Navedeno je popraćeno poglavljima o metodologiji i procesu istraživanja, rezultatima i zaključnim razmatranjima.

${ }^{5}$ Commercial awareness ili acumen označava vještinu razumijevanja faktora koji poduzeće čine uspješnim, i faktora koji utječu na uspjeh. Također, vještinu onoga koji je u tijeku sa svakodnevnim događajima u poslovnom i komercijalnom svijetu. 


\section{Pregled literature}

Kao glavni makroekonomski utjecaji koji utječu na promjene u kontrolingu navode se globalizacija tržišta, napredak u informacijskim i proizvodnim tehnologijama te povećanje konkurencije. Na organizacijskoj razini, promjene uključuju veći naglasak na ključnim kompetencijama (eng. core competencies), odnosu prema kupcima, dobavljačima, smanjivanju broja zaposlenih, outsourcingu, plićoj organizacijskoj strukturi te timskom radu (Forsaith, Tilt, Xydias-Lobo, 2004, str. 3-4).

Nadalje, determinante koje utječu na razvoj uloga kontrolera i koje su se evaluirale u prethodnim istraživanjima su: razina konkurentnosti, tehnološki razvoj, suradnja između funkcija, uvođenje inovacija u procese kontrolinga, kao i individualne kvalitete kontrolera (Byrne, Pierce, 2007, str. 473-474). Primjerice, Hartman i Maas (2011, str. 453) istraživali su utjecaj neizvjesnosti i ulogu budžeta pri definiranju uloge kontrolera i razlika uloga kontrolera među poduzećima. Zatim, prema spoznajama iz istraživanja Byrne i Pierce (2007, str. 480) obrazovanje i prijašnji tijek poslovne karijere kontrolera utječe na dominantnu ulogu kontrolera, kao i menadžeri s kojima surađuju. Također, velik broj ispitanika je poslovno znanje, interpersonalne i komunikacijske vještine i fleksibilnost identificirao kao značajne vještine (Byrne, Pierce, 2007, str. 480). Osim istraživanja determinanti uloga kontrolera, istraživali su se i učinci pojedinih uloga (Byrne, Pierce, 2007, str. 474). Organizacijske uloge kontrolinga predstavljaju značajnu dugogodišnju temu istraživanja, gdje su pojedini autori nastojali razviti klasifikacije uloga (Hartman, Maas, 2011, str. 439). Prema teoriji uloga (eng. role theory), organizacijske uloge su rezultat očekivanja ostalih članova organizacije (Byrne, Pierce, 2007, str. 471).

Kontroleri današnjice najčešće preuzimaju sljedeće uloge unutar organizacije: 1) nadzornik, (eng. Steward), odgovoran za upravljanje rizikom i očuvanje imovine, 2) operater (eng. Operator), koji na efikasan i efektivan način prati i izvještava o ostvarenju operativnog učinka poslovanja, 3) strateg (eng. Strategist), koji utječe na budući smjer kretanja organizacije, i 4) katalizator (eng. Catalyst), odgovoran za pokretanje i implementaciju promjena u organizaciji kako bi se postigli strateški financijski ciljevi (Waelter i sur., 2018, str. 2), od kojih strateg i katalizator daju najveću vrijednost poslovanju (Deloitte, 2012).

Schäffer i Weber klasificiraju 12 različitih uloga kontrolera (2015a, str. 140):

- interni konzultant (eng. Internal Consultant) - pored funkcije pružanja informacija u obliku brojeva, kontroler obavlja i savjetodavnu funkciju kao npr. predlaganje korektivnih mjera u budžetu,

- sparing partner menadžmentu (eng. Economic Conscience) - kontroler obavlja funkciju kritičkog preispitivanja aktivnosti menadžmenta, 
- inspektor (eng. Inspector) - kontroler mora imati određenu dozu razvijene emocionalne inteligencije kako bi se izbjegle negativne posljedice nadzora npr. u slučaju otkrivanja greški,

- navigator (eng. Pilot) - kontroler je zadužen za održavanje korporativne politike u skladu sa zadanim ciljevima,

- perfekcionist (eng. Bloodhound/Watchdog(Vaivio, 2006, str. 198)) - kontroler koji je uporan u racionaliziranju i konstantno traži i vidi prostora za napredak,

- komunikator (eng. Communicator) - naglasak je na odnosu kontrolermenadžer. Kontroler mora omogućiti ključne podatke i implikacije istih na odgovarajući način kako bi postigao pozitivan učinak na akcije menadžera,

- brojač graška (eng. Bean Counter) - ovaj profil kontrolera promatra sve kroz brojeve i njegova primarna funkcija je informativna,

- agent promjena (eng. Change Agent) - zahvaljujući njihovoj samostalnosti, kontroler je u dobroj poziciji doprinijeti prihvaćanju promjena i njihovom nadzoru,

- „partibrejker"““ (eng. Wet Blanket) - kontroler ovdje preuzima ulogu filtera u procesu planiranja i budžetiranja i ima zadatak implementiranja rezova,

- inovator (eng. Innovator) - dosada je ta uloga bila podređena u interakciji kontroler-menadžer; kontroler preuzima dio uloga menadžera,

- arhitekt (eng. Architect) - kontroler nema slobodu formirati aktivnosti unutar organizacije,

- dvorska luda (eng. Court Jester) - ova uloga opisuje činjenicu da je kontroler jedina osoba u poduzeću koja može izraziti ‘bolnu' istinu bez straha od negativnih reperkusija.

Općenito, različite uloge unutar kontrolinga mogu se podijeliti na reaktivne (naglasak na računovodstvu) i proaktivne (naglasak na cjelokupnom poslovanju). Svjetska konzultantska kuća PricewaterhouseCoopers (2017a, str. 7) kategorizirala je uloge kontrolera stavljajući na reaktivnu stranu ulogu zapisničara (eng. Scorekeeper) i komentatora, a na proaktivnu ulogu poslovnog partnera i čuvara (eng. Caretaker). Gupta, Copleston i Malhotra (2016, str. 2) ukazuju na trimodalnu ulogu kontrolera današnjice koja se sastoji od sljedećih uloga: čuvar troškova (eng. Guardian of costs), poticatelj razvoja (eng. Growth champion) i menadžer rizika i usklađivanja (eng. Manager of risk and compliance).

\footnotetext{
${ }^{6}$ Slobodan prijevod autora, istoj ulozi je moguće pridjenuti drugačiju terminologiju.
} 


\section{Perspektiva u razvoju kontrolinga - Business Partnering}

Eksplozija u kvantiteti i varijacijama dostupnih podataka, novi poslovni modeli kao rezultat promjena na tržištu te prilike stvorene digitalizacijom potaknule su razvoj uloge kontrolera kao poslovnog partnera tj. eng. business partnera (Deloitte, 2012, str. 1). Šira definicija business partneringa obuhvaća suradnju kontrolera s drugim poslovnim funkcijama kako bi osigurao financijske informacije, alate, analizu i spoznaju. Danas je to široko prihvaćen termin kako bi se opisao odnos između internih stručnjaka i poslovnih jedinica u kojem dolazi do slamanja konvencionalnih, zatvorenih struktura s ciljem povećanja poslovnih performansi, učinkovitijeg upravljanja troškovima i otvaranja raznih strateških perspektiva (CPA Australia, 2016, str. 4).

Kontroler kao business partner ima snažno utvrđen odnos s menadžerima (Quinn, 2014, str. 24) te Järvenpää (2007) definira poslovnu orijentaciju kontrolera kao spremnost $i$ sposobnost kontrolinga da kreira dodanu vrijednost ${ }^{7}$ menadžmentu (u području odlučivanja i kontrole). Ova definicija ističe važnost osobne želje te potrebnih vještina kako bi se postalo poslovnim partnerom, naglašavajući važnost sudjelovanja kontrolera u procesu odlučivanja. Iz navedenog slijedi zaključak da ako kontroleri postanu poslovni partneri bolje će pružati proširene usluge izvršnim direktorima i doprinositi postignuću organizacijskih ciljeva (Wolf, Weißenberger, Wehner i Kabst, 2015, str. 25).

Business partner modelom se smatra uključenost kontrolera u donošenje strateških i operativnih odluka kroz integraciju financijskih i nefinancijskih informacija (Byrne i Pierce, 2007, str. 470-471). Nadalje, kontrolerima uloga business partnera znači naglasak na strateškim, budućnosti orijentiranim, inovativnim aktivnostima, gdje se u istraživanjima uz tradicionalna znanja očekuju i analitičke i sociološke vještine (Byrne i Pierce, 2007, str. 471). Kao savjetodavni članovi organizacijskog tima, poslovni partneri ključni su agenti za provođenje strategije i oblikovanje aktivnosti koje pridonose vrijednosti poduzeća kroz cijelo poduzeće, kao i za usađivanje etosa koji iziskuje efikasnost i kontinuirani napredak (Burns, Warren i Oliveira, 2014, str. 38). Nisu više dio tima isključivo za podršku, već mogu predstavljati značajne generatore poslovne vrijednosti.

Tradicionalno, kontroleri bi većinu svog vremena posvetili rutinskom prikupljanju podataka, suočavajući svoje kolege sa njihovim performansama spram postavljenih financijskih normi i pripremajući rutinske računovodstvene izvještaje. Nasuprot tome, današnji se poslovni partneri više uključuju u savjetodavne i analitičke dužnosti integrirajući informacije iz različitih dijelova organizacije i objaš-

${ }^{7}$ Ovdje se na dodanu vrijednost gleda kao na mjeru sustava za postizanje ciljeva odnosno za poticanje vrhovnog menadžmenta (performance management) 
njavajući međusobnu povezanost nefinancijskih pokazatelja performansi i konvencionalnih financijskih mjerila (International Controlling Association, 2012, str. 6).

Tipični zadaci kontrolera kao poslovnog partnera uključuju sljedeća područja djelovanja (Burns, Warren i Oliveira, 2014, str. 38):

- korporativna strategija: budući da je situiran u strateškom srcu organizacije, zadatak mu je povezivati strateško sa operativnim;

- menadžment promjena: pokretanje i provođenje organizacijskih promjena, proaktivnije za razliku od prije kad je sudjelovao samo kao podrška;

- CRM menadžment: stvaranje i komuniciranje informacija kako bi se kontinuirano radilo na poboljšanju razumijevanja potreba potrošača;

- razvitak sustava: utjecanje na dizajn, menadžment i kontinuirani razvitak širih informacijskih sustava;

- upravljanje rizicima: identificiranje, mjerenje i nadzor rizika i gdje je moguće, preveniranje rizika ili minimiziranje nastalih šteta.

Poslovni partneri postaju eksperti u pripremi, interpretaciji i širokoj upotrebi informacija. Posljedično tome, mogu biti locirani u središtu intra- i ekstra organizacijskih informacijskih tokova (Burns i sur., 2014, str. 38).

Poslovni partneri također, integriraju dnevne aktivnosti i težnje za višim strategijskim organizacijskim ciljevima. Sukladno tome, rade uz svoje kolege iz različitih odjela kao integralni članovi menadžerskog tima i kontinuirano povezuju financijske i nefinancijske informacije sa širim informacijskim tokovima unutar organizacije (Burns i sur., 2014, str. 39).

U istraživanju konzultantske kuće Robert Half Management Resources u suradnji s Longitude Research provedenom na uzorku od 1000 financijskih direktora u Velikoj Britaniji, Francuskoj, Belgiji, Njemačkoj i Nizozemskoj 2012. godine, ispitanici su istaknuli iscrpno znanje i duboko razumijevanje industrije u kojem poduzeće posluje ali i općenito poslovanja, snažne analitičke vještine, vještina vođenja te duboko znanje o konkurenciji i ekonomskom okruženju poduzeća kao najvažnije vještine kontrolera kao business partnera (Robert Half Management Resources, 2012, str. 11). Ostala istraživanja pokazuju slične rezultate. Primjerice, istraživanje provedeno od strane CPA Australia 2013. godine, ističe sljedeće kompetencije kao ključne u business partnera: komercijalna sposobnost (eng. commercial acumen) i odlučivanje, vještina mijenjanja status quo, pregovaranja, utjecanja, strateški način razmišljanja, analitičke sposobnosti te menadžment odnosa (CPA Australia 2016, str. 11). Drugo istraživanje provedeno od strane PwC 2017. ističe analitičke vještine, komunikaciju i upravljanje odnosima te poznavanje organizacije kao tri najvažnije karakteristike business partnera (PwC, 2017a, str. 16). Tablica 1. sumira glavne vještine business partnera. 


\section{Tablica 1 .}

\section{POPIS POTREBNIH VJEŠTINA BUSINESS PARTNERA}

\begin{tabular}{|c|c|}
\hline \multicolumn{2}{|c|}{ Potrebne vještine } \\
\hline 'Tvrde' vještine & 'Meke' vještine \\
\hline $\begin{array}{l}\text { - IT vještine: sposobnost asistiranja IT } \\
\text { ekspertima i statističarima u dizajnu } \\
\text { i razvoju informacijskih sustava, } \\
\text { integrirajući najnovije tehnologije; } \\
\text { - široko razumijevanje raznih poslovnih } \\
\text { aspekata: raznoliko poslovno iskustvo, } \\
\text { kako bi pomogao manje financijski } \\
\text { 'mudrim' kolegama u procjeni } \\
\text { performansi i poduzimanju lokalnih } \\
\text { odluka }\end{array}$ & $\begin{array}{l}\text { - komunikacija: sposobnost prenošenja } \\
\text { informacija koje nudi kontroling } \\
\text { različitim korisnicima, na njima } \\
\text { razumljiv način; } \\
\text { - Interpersonalne: razvijene } \\
\text { interpersonalne vještine, kao i vještina } \\
\text { izgradnje odnosa povjerenja među } \\
\text { kolegama kroz cijelu organizaciju; } \\
\text { - uvjerljivost: velika sposobnost } \\
\text { uvjeravanja kako bi se progurale ideje i } \\
\text { sposobnost nošenja s različitim tipovima } \\
\text { osobnosti, razinama zrelosti i načinima } \\
\text { gledišta }\end{array}$ \\
\hline
\end{tabular}

Izvor: izrada autora prema Burns, J., Warren, L., Oliveira, J. (2014) Business Partnering: Is It All That Good? Controlling \& Management Review, str. 40.

Može se utvrditi kako uloga poslovnog partnera obuhvaća i rutinske poslovne aktivnosti, ali i nove temeljne razvojne inicijative, npr. uspostavljanje orijentacije prema dodanoj vrijednosti ili održivosti u korporativnom upravljanju. Fokus poslovnog partnera je prepoznati i unaprijediti takve teme (Gänßlen, Losbichler, Niedermayr, Rieder, Schäffer i Weber, 2012, str. 5). Pri tome je iznimno važno da kontroleri postignu ravnotežu između aktivnog sudjelovanja u procesu upravljanja u koji unose vlastite ideje $\mathrm{s}$ jedne strane, i njihove restriktivne funkcije čuvara interesa poduzeća i sparing-partnera s druge strane.

\section{Doprinos kontrolera kao poslovnog partnera poduzeća}

Tri su glavna doprinosa business partneringa: 1) menadžment donosi bolje odluke, 2) omogućava strateške inicijative, i 3) unaprjeđuje financijske performanse (CPA Australia 2016, str. 5). No, business partnering jednako doprinosi i kontrolerima i menadžerima što u konačnici ima multiplikativan efekt na poslovanje poduzeća, vidljivo u Tablici 2. 
Tablica 2.

\section{DOPRINOS BUSINESS PARTNERINGA}

\begin{tabular}{|c|c|}
\hline \multicolumn{2}{|c|}{ Prednosti njegovanja business partnering kulture } \\
\hline Za menadžment/poslovanje: & Za kontroling: \\
\hline $\begin{array}{l}\text { - disperzija vlasništva nad odlukama u } \\
\text { organizaciji vodi ka većoj vjerojatnosti } \\
\text { približavanja ili postizanja postavljenih } \\
\text { ciljeva i konkurentske prednosti }\end{array}$ & $\begin{array}{l}\text { - članovi kontrolinga postaju integralni } \\
\text { dio poslovanja }\end{array}$ \\
\hline $\begin{array}{l}\text { - stvaranje sinergija između različitih } \\
\text { business partnering uloga kroz suradnju } \\
\text { s raznim poslovnim jedinicama pomoći } \\
\text { će formiranju jasnije slike odgovornosti i } \\
\text { izbjegavanja duplikacije vremena i truda }\end{array}$ & $\begin{array}{l}\text { - funkcija kontrolinga postaje sve } \\
\text { cjenjenija, što zauzvrat povećava osobnu } \\
\text { motivaciju i zadovoljstvo kontrolera }\end{array}$ \\
\hline $\begin{array}{l}\text { - boljim informacijama i koordinacijom } \\
\text { poboljšat će se proces odlučivanja }\end{array}$ & $\begin{array}{l}\text { - pred kontrolerima se otvaraju karijerne } \\
\text { mogućnosti prema više komercijalno } \\
\text { orijentiranim ulogama kao što su pozicija } \\
\text { izvršnog ili financijskog direktora }\end{array}$ \\
\hline
\end{tabular}

Izvor: izrada autora prema PwC, 2009. Adding up or adding Value? Making business partnering work. Preuzeto s https://www.pwc.co.uk/assets/pdf/adding-up-or-adding-value.pdf (23.01.2019.) str. 4.

Integracija informacija pomaže menadžerima da uoče poveznice između lokaliziranih aktivnosti i da razumiju kako te aktivnosti doprinose sveopćoj financijskoj i strateškoj performansi (International Controlling Association, 2012, str. 11)

Ako generalni direktori ili menadžeri nemaju pozitivan stav prema poslovnom partneru kao ulozi kontrolera i ako uz to ne očekuju od kontrolera sudjelovanje u procesu odlučivanja, kontroleri će neminovno ostati u svojoj tradicionalnoj ulozi. Slijedom toga, dva važna faktora koja utječu na kontrolerovu participaciju u menadžerskom procesu odlučivanja i poslovnoj orijentaciji jesu: prvo, osobna volja (karakteristike) kontrolera, a drugo, očekivanja menadžmenta (karakteristike menadžera) (Wolf i sur., 2015, str, 27).

Također, organizacije s najboljim poslovnim rezultatima pružaju više koristi business partneru definiranjem jasnih granica između različitih uloga kontrolinga. Uloga kontrolera kao zapisničara (scorekeeper-a) će i dalje većinom biti zadužena za dostavu standardnih menadžerskih informacija dok će business partner biti zauzet interpretiranjem tih informacija u moguće implikacije stakeholderima (PwC, 2017a, str. 18). Ključan kulturološki doprinos koji proizlazi iz business partneringa je stvaranje kulture koja izaziva stare, a stimulira, ohrabruje i stvara nove ideje (CPA Australia, 2016, str. 10). 


\section{Business partnering u praksi}

Recentna analiza PwC-a pokazuje da business partneri u praksi troše jedva 50\% svog vremena na prave business partnering aktivnosti (PwC, 2017b, str. 14). Istraživanje Deloitte-a iz 2018. godine potvrđuje da većina kontrolera troše približno 70\% svog vremena na tradicionalne uloge (Operator i Steward uloge) (Waelter i sur., 2018, str. 3). Kao glavna ograničenja business partneringu navode se neadekvatni IT sustavi, preveliki fokus na ostale aktivnosti kontrolinga te manjak pravih sposobnosti i znanja unutar trenutnog kadra kontrolinga. Većina problema povezanih uz IT su uzrokovana implementacijom takvih sustava. Organizacije ne uspijevaju točno prevesti strategiju organizacije u komplementarno IT rješenje koje generira željene spoznaje (PwC, 2017a, str. 18).

Kao posljedica razvoja uloge business partnera u organizacijama i među samim kontrolerima javlja se sukob uloga, odnosno definiranja i provedbe ključnih zadataka (Byrne i Pierce, 2007, str. 474). S jedne strane, u svojoj tipičnoj ulozi, kontroleri imaju dužnost provođenja standarda, smjernica i očekivanja performansi definiranih od nadređenih tokom koje nadziru menadžere. A, s druge strane, u ulozi business partnera podupiru menadžere u procesu odlučivanja te se od njih očekuje da po potrebi zastupaju i brane interese operativnih menadžera ispred nadređenih. Takva dualna odgovornost rezultira konfliktom koji cee biti izraženiji što su više kontroleri uključeni u proces odlučivanja (Goretzki, Lukka i Messner, 2018, str. 701).

Uloga poslovnog partnera omogućuje kontroleru intenzivnu suradnju s menadžmentom na širem području tema. To je rezultat promjena i kontrolera i menadžera. S jedne strane, današnji menadžeri su, zahvaljujući modernim trening programima i uspješnoj suradnji s kontrolerima, razvili jako dobre poslovne vještine. Sukladno tome, više ne trebaju pomoć kontrolera. S druge strane, današnji menadžeri imaju i efektivna IT rješenja koja su im dostupna što znači da sami mogu doći do informacije koja im treba (tzv. „self service“) (Scäffer i Weber, 2015b, str. 3).

Iz perspektive kontrolera, oni su tokom godina razvili menadžerski knowhow. Jednako dobro rješavaju zadatke koji se tiču organizacije ili zaposlenika kao i tradicionalne financijske teme. Štoviše, kontroleri su, do trenutka kada dođu na poziciju poslovnog partnera, stekli mnoštvo poslovnog znanja.

Danas postoje značajna preklapanja aktivnosti menadžera i kontrolera te se postavlja pitanje u kojem trenutku kontroleri više neće biti potrebni (tzv. „,self controlling") (Scäffer i Weber, 2015b, str. 4). Ključni aspekti koji se moraju uzeti u razmatranje pri odgovoru na potonje pitanje jesu važnost funkcije sparing partnera menadžmentu i stupanj inovativnosti u poslovnim procesima, koji oboje jačaju slučaj protiv odbacivanja uloge kontrolera. 
Uspjeh poslovnog partnera ovisi o kvaliteti rada stručnjaka jer suradnici poslovnog partnera nisu samo unutar menadžmenta već i unutar odjela kontrolinga u formi stručnjaka koji rade preliminarni posao za njih, osiguravajući im procjene i kvalitetu brojki. To uključuje sve zadatke koje kontroleri obavljaju u izravnom kontaktu s menadžerima (Scäffer i Weber, 2015c, str. 1). Suočavamo se s pitanjem kako zvati kontrolere koji nisu poslovni partneri? Često za takve slučajeve čujemo izraz „,profesionalci“ ili „stručnjaci“. Oni se danas suočavaju s naročito neizvjesnom budućnosti u profesionalnom smislu. Opseg njihovih aktivnosti je pod prijetnjom opcija kao što su standardizacija ili automatizirana IT rješenja (Tomić, 2015).

Utjecaj novih tehnologija poput Big Data, prediktivne analitike, umjetne inteligencije (AI), blockchain i cognitive computing tehnologije, strojnog učenja (eng. machine learning) te robotics process automation (RPA) eliminirat će tipičnu ulogu kontrolera i razviti je u business partnera (Lawson, 2018, str. 05).

\section{Daljnji trendovi razvoja kontrolinga i uloge kontrolera}

Korporativni financijski kontroling će i dalje obavljati tradicionalne zadatke, ali će preuzeti novu poziciju unutar organizacije. Kontroleri će se uglavnom razviti u business partnere menadžmentu, a usluge korporativnog financijskog kontrolinga će biti povučene i nuđene centralno iz tzv. Shared Service Centre (SSC) (Zastrow, 2016, str. 05). SSC je pružatelj usluga za kupce unutar organizacije, a usluge koje će nuditi mogu se sažeti u sljedeće aktivnosti: 1) računovodstvo troškova, aktivnosti i poslovnih rezultata; 2) izvještavanje menadžmenta; 3) strateško i operativno planiranje te 4) predviđanje (Zastrow, 2016, str. 10). Na taj način, rutinske aktivnosti će u potpunosti postati automatizirane, a količina raspoloživih podataka će se povećati. Predviđa se kako će kontroling postati čuvar tih podataka na način da će postaviti smjernice, nadzirati usklađenost s istima i osigurati da se podaci koriste na pravilan način, dok će business partnering u tom slučaju igrati važnu ulogu u prevođenju tih podataka u pravu informaciju i prenošenju ostalima u organizaciji (PwC, 2017a, str. 21).

S razvojem tehnologije razvijaju se, nestaju i stvaraju pojedini poslovi. Studija provedena od Forrester Research, Inc., predviđa gubitak od $72 \%$ poslova u području menadžmenta, financija i kontrolinga koji će biti eliminirani tehnologijom do 2020. godine (Lawson, 2018, str. 6). Isto tako, procijenjeno je da automatizacija ima potencijal eliminirati 40\% rutinskog posla kontrolinga do 2020. godine (Lawson, 2018, str. 8). Shodno tome, zadaci kontrolera su se u skladu s Big Data i poslovnim analitikama korjenito promijenili, gdje je naglasak sa pri- 
preme podataka prešao na analize $\mathrm{i}$ interpretacije podataka $\mathrm{i}$ informacija dobivenih automatizacijom i robotizacijom. Navedenim razvojem raste i značaj, kao i atraktivnost posla kontrolera u smjeru business partnera i poboljšanja donošenja odluka (Weber, 2018). Također promjene zahtijevaju i nužne prilagodbe edukacija za kontrolere (Weber, 2018).

Kvalitetna poslovna prognostika (eng. business forecast) omogućuje realni prikaz budućeg poslovnog razvoja te pruža uvid u prilike i prijetnje. Danas se za potrebe kontrolinga sve više koriste i računalni forecasti, odnosno putem primjene najnovijih informacijskih tehnologija omogućuju se interaktivni dashboard-i. Također, navedeni pristup omogućio je kvalitetan razvoj poslovne (eng. Business analytics) i prediktivne analitke (eng. Predictive Analytic Forecast), koji su u znatnoj mjeri točniji od standardnih projekcija samih kontrolera, pogotovo u modelu poslovanja „business as usual“(Weber, 2018). Na taj način moći će se preusmjeriti vrijeme i resursi kontrolera od osnovnih projekcija ka planiranju iznimaka, što bi u konačnici povećalo sveukupnu kvalitetu forecasta. Također, današnje planiranje se razvija, osim u smjeru forecasta, i u smjeru upravljanja putem ciljeva, koje se služi metodama scenario planiranja i primjenom prediktivne analitike (Schäffer, 2017). Pri primjeni današnjih modela, koriste se koncepti i znanja od računalnog učenja/umjetne inteligencije, statistike, optimizacije poslovanja do Big Data (Schäffer, 2017).

Kako bi kontroler bio u trendu s navedenim, trebao bi se značajnije pozabaviti i upoznati s digitalizacijom poslovanja, kao i aktivno raditi na povećanju sposobnosti procjene, jer u protivnom, ukoliko kontroleri neće biti u mogućnosti komunicirati potrebe i razumjeti domete digitalizacije, nestat će i potrebe za kontrolerima (Schäffer, 2017). Upotreba alata, a ne razvoj novih, smatra se najkritičnijim za implementaciju i adaptaciju novih pristupa (Clinton i White, 2012, str. 43). Prema istraživanju konzultantske kuće KPMG iz 2016. godine na uzorku od 202 kontrolera, najveći izazovi koje tehnologija predstavlja za odjel kontrolinga jesu stvaranje silosa između kontrolinga i IT-a ${ }^{8}$, manjak ljudskog kadra s IT znanjem, sve veći zahtjevi za sve većom količinom podataka i analizama, manjak podrške vrhovnog menadžmenta te izostanak potrebne edukacije (Forbes Insights, 2016, str. 14).

Nadalje, na primjeru poduzeća BASF, vidljiva je daljnja evolucija uloga kontrolera u praksi. Tako su u sklopu strategije "Controlling 2025" definirane četiri uloge kontrolera (Schäffer, 2017):

1. Poslovni partner (eng. Business partner) - uloga koja pruža sveobuhvatnu podršku menadžerima je značajna, no ne i ekskluzivna;

${ }^{8} \mathrm{U}$ poslovnom upravljanju i informacijskoj tehnologiji (IT) silos opisuje bilo koji sustav upravljanja koji ne može raditi s bilo kojim drugim sustavom, što znači da je zatvoren od drugih sustava. Silos stvara okruženje individualnih i različitih sustava unutar organizacije. 
2. Čuvar (eng. Guardian) - uloga kontrolera koja se brine za usklađenost s pravilima, praksama i procesima, upravljanje rizicima i ostvarivanje ciljeva od strane menadžera;

3. Stručnjak (eng. Service expert) - uloga kontrolera koji ocjenjuje koje zadaće se kvalitetnije mogu obaviti u kontrolingu naspram SSC-a;

4. Vodič (eng. Pathfinder) - kao odgovor na digitalnu transformaciju, poslovnu neizvjesnost i disrupciju uloga se bavi prepoznavanjem budućih trendova, digitalizacijom i unaprjeđenjem analitičkih kapaciteta, kao i primjenom istih pri rješavanju konkretnih izazova s kojima se poduzeća susreću.

Naglasak na podacima kao ključnim faktorom poboljšanja performansi poslovanja zahtijeva vještinu ovladavanja tzv. podatkovno orijentiranim procesom stvaranja vrijednosti (eng. data-centric value adding process) koji stvara novu ulogu: podatkovni znanstvenik (eng. data scientist). Ova uloga podrazumijeva dizajn strategije podataka koja je relevantna i izvodljiva te ekstrakciju informaciju iz velike količine podataka. $U$ tom procesu, podatkovni znanstvenici kombiniraju analitičke sposobnosti s poslovnim znanjem te se postavlja pitanje hoće li podatkovni znanstvenici zamijeniti kontrolere ili će te dvije uloge koegzistirati, i ako da, uz kakvu relaciju između njih (Lawson, 2018, str. 9).

Umjetna inteligencija (eng. AI- Artificial Intelligence) i analitika zahtijevaju ne samo podatkovne znanstvenike već i kros-funkcionalne timove koji se sastoje od podatkovnih inženjera (eng. data engineers), arhitekata (eng. data architects), stručnjaka u vizualizaciji podataka (eng. data-visualization experts) i najvažnije - prevoditelja (eng. analytics translators). Prevoditelji imaju ključnu ulogu u povezivanju tehničke stručnosti podatkovnih znanstvenika s operativnom stručnosti menadžera u marketingu, lancu opskrbe, proizvodnji, riziku i ostalim operativnim funkcijama (Henke, Levine i Mclnerney, 2018).

\section{Metodologija i proces istraživanja}

Svrha empirijskog istraživanja jest stoga utvrditi koje ključne kompetencije kontroler mora imati i razvijati te posljedično tome, koje uloge treba preuzimati unutar odnosa kontroler - menadžer, ali i unutar poduzeća općenito u okvirima hrvatske poslovne sfere. Time se želi dati projekcija budućeg razvoja uloge kontrolera u poduzeću.

Empirijsko istraživanje „Potrebne kompetencije i uloga kontrolera u poduzeću“ obuhvaćalo je uzorak od 500 srednjih i velikih poduzeća, svih županija 
Republike Hrvatske s obzirom na razinu prihoda prema podacima Hrvatske gospodarske komore iz 2015. godine. Razlog odabira srednjih i velikih poduzeća jest pretpostavka postojanja kontrolinga u institucionalnom smislu, kako bi se dobila realnija slika uloge kontrolera u hrvatskim poduzećima. Istraživanje je provedeno elektronskim putem, i to pomoću anketnog upitnika, oblikovanog temeljem WHU - Controller Panel istraživanja objavljenog od strane vodećih njemačkih autoriteta na području kontrolinga dr. U.Schäffer i dr. J. Weber (Schäffer i Weber, 2015a, str. 132-150). Anketni se upitnik sastojao od dva dijela odnosno, od općeg dijela (podataka o ispitaniku i poduzeću) i od glavnog dijela istraživanja - procjene ispitanika o tome koje su potrebne kompetencije i kako se manifestira uloga kontrolera u njihovom poduzeću. Svi upitnici su ispunjeni online te su evidentirani u bazu podataka. Provedeno je presječno istraživanje (eng. Cross sectional study) koje je trajalo od mjeseca veljače do svibnja 2017. godine, a u navedenom je razdoblju zaprimljeno ukupno 130 uredno ispunjenih anketnih upitnika (26\% stopa povrata). Ispitanicima je zajamčena sigurnost i tajnost podataka, a 58,4\% ispitanika (76 ispitanika) zatražilo je uvid u konačne rezultate istraživanja. Pri obradi

podataka korištene su statističke metode, a sve u svrhu ostvarivanja već prethodno spominjanih ciljeva istraživanja.

\section{Rezultati istraživanja}

\section{Struktura ispitanika istraživanja}

Rezultati istraživanja uloge kontrolera u hrvatskim poduzećima temelje se na 130 ispunjenih anketa odnosno na odgovorima 130 različitih poduzeća u Republici Hrvatskoj. Unutar uzorka zaprimljeno je 67\% odgovora ispitanika koji pripadaju velikim te $33 \%$ odgovora ispitanika koji pripadaju srednje velikim poduzećima.

Struktura djelatnosti poduzeća obuhvaćenih empirijskim istraživanjem prikazana je Tablicom 3. 
Tablica 3.

\section{STRUKTURA DJELATNOSTI PODUZEĆA IZ UZORKA}

\begin{tabular}{|l|c|}
\hline Poslovna djelatnost: & $\%$ \\
\hline Prerađivačka industrija & 9,2 \\
\hline Proizvodnja robe široke potrošnje & 9,2 \\
\hline Građevinarstvo & 7,7 \\
\hline Trgovina, održavanje i popravak automobila & 6,9 \\
\hline Financijske usluge i osiguranje & 3,8 \\
\hline Javna uprava i javni sektor & 3,1 \\
\hline Proizvodnja i prerada metala & 3,1 \\
\hline Proizvodnja kemijskih proizvoda & 2,3 \\
\hline Opskrba električnom energijom i vodom & 2,3 \\
\hline Informatička tehnologija & 1,5 \\
\hline
\end{tabular}

Izvor: istraživanje autora

Od navedenih ispitanika tražilo se da procjene posluje li njihovo poduzeće u razini, iznad ili ispod prosjeka industrije prema kriteriju dobiti te se prema rezultatima može zaključiti da dominiraju poduzeća koja posluju u razini $(52,3 \%)$ i iznad $(43,1 \%)$ prosjeka industrije.

Kako bismo razumjeli uloge kontrolera, bilo je potrebno ispitati iskusne kontrolere i menadžere te su stoga odabrani u ciljane ispitanike. Većina ispitanika koji su ispunili anketni upitnik su na vodećim pozicijama u odjelu kontrolinga poduzeća u kojem rade bilo kao voditelj/ica ili /rukovoditelj/ica ili financijski kontroler. 


\section{Rezultati istraživanja sadašnjih i budućih uloga i kompetencije kontrolera u poduzeću}

\section{Grafikon 1.}

\section{ZNAČAJ SADAŠNJIH I BUDUĆIH ULOGA I KOMPETENCIJA KONTROLERA}

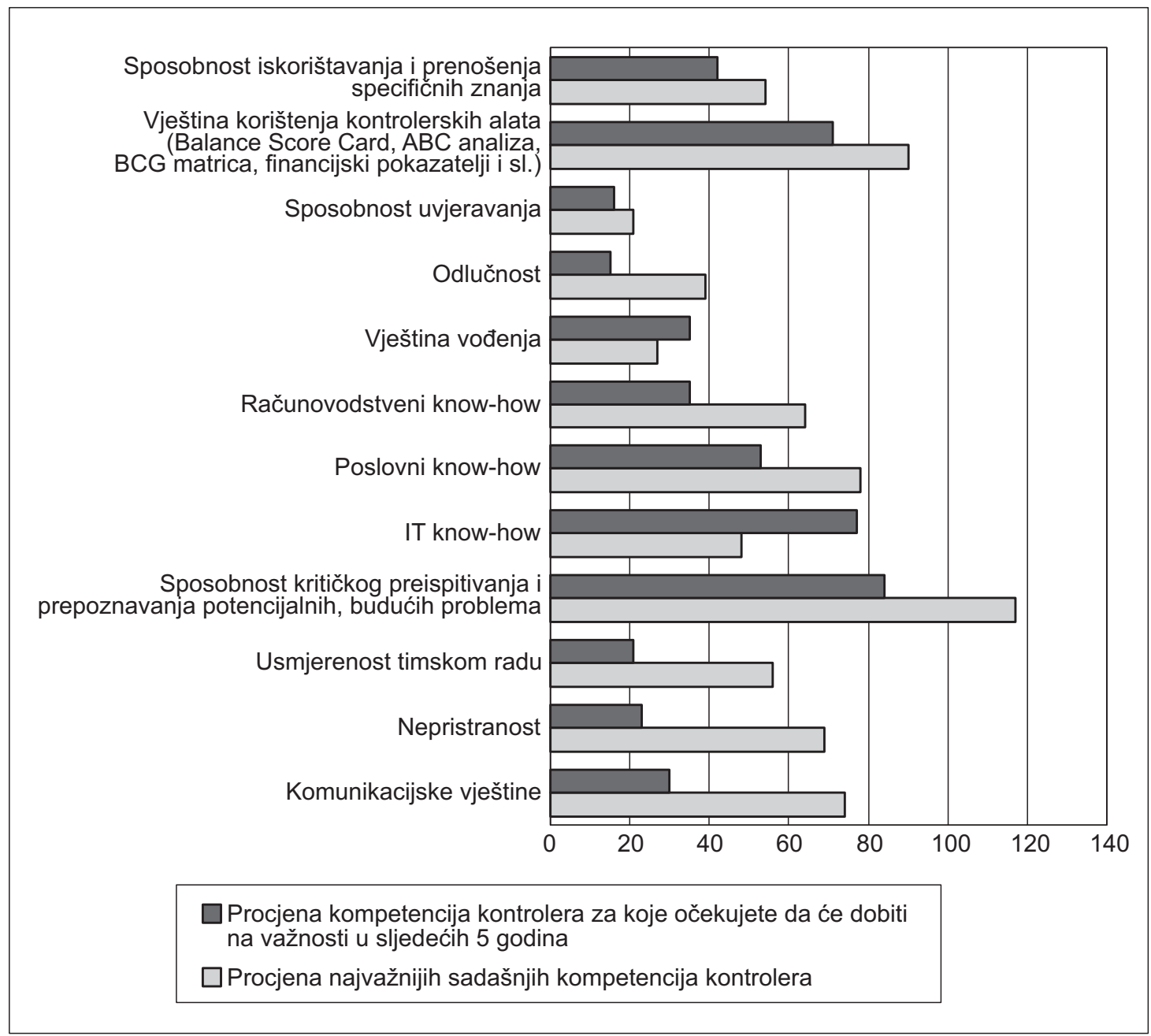

Napomena: bilo je moguće označiti više odgovora

Izvor: istraživanje autora 
Uvidom u grafikon 1., možemo uočiti promjene u značaju pojedinih kompetencija i vještina koje bi kontroleri trebali posjedovati danas, u odnosu na kompetencije i vještine kontrolera koje se očekuju da će dobiti na važnosti u sljedećih 5 godina. U budućnosti se očekuje značajnija primjena IT know-howa u kontrolingu, kao i porast vještina vođenja, dok će značajnima ostati sposobnosti kritičkog preispitivanja i prepoznavanja potencijalnih i budućnih problema, kao i vještine korištenja kontrolerskih alata, iako s relativno manjom frekvencijom ispitanika koji se slažu s navedenim tvrdnjama u odnosu na iste vještine danas.

Navedeni rezultati koreliraju s razvojnim smjerom kontrolinga budući da je jedna od pretpostavki razvoja business partneringa razvoj i implementacija adekvatnih IT sustava koji će zamijeniti rutinske poslove kontrolera i time stvoriti vrijeme za strategijske razine aktivnosti, dok s druge strane preuzimanje odgovornosti u procesu odlučivanja, suradnja s drugim odjelima te uloga prevođenja podataka dobivenih od podatkovnih znanstvenika menadžerima opravdavaju porast vještine vođenja kao bitne odlike kontrolera kao budućeg business partnera. Vještine sposobnosti kritičkog preispitivanja i prepoznavanja potencijalnih i budućih problema, kao i korištenja kontrolerskih alata i dalje ostaju značajne te time sukladne literaturi koja tvrdi da je miskoncepcija da će uloga kontrolera kao nadzornika (eng. watchdog) nestati već će te vještine opstati kao svojevrsna higijena. Prema navedenim rezultatima, razvoj kontrolera u RH je trenutno na razini sparing partnera što ukazuje na višu dimenziju kontrolera koja u budućnosti ima potencijal razvitka u business partnera.

\section{Wilcoxon test}

U narednom dijelu empirijskog istraživanja, kako bi se spoznale tendencije razvoja pojedinih uloga kontrolera, evaluirala su se pitanja koja se odnose na „U kojoj mjeri Vas najčešće doživljava menadžment Vašeg poduzeća/ organizacije?“ i „Kroz koje uloge i u kojoj mjeri bi ste najviše željeli da Vas menadžer percipira?“

Evaluirale su se sljedeće uloge kontrolera u oba pitanja, a koje se navode u prethodno navedenoj literaturi i koje su ukratko objašnjene u narednim tablicama: Interni konzultant; Sparing partner; Inspektor; Navigator; Perfekcionist; Komunikator; Brojač graška; Agent promjena; Partibrejker; Inovator; Arhitekt i Dvorska luda (Grafikon 2. Prosječne ocjene percepcija sadašnih uloga kontrolera i uloga kroz koje bi u budućnosti kontroleri željeli da ih menadžeri percipiraju). 


\section{Grafikon 2.}

\section{PROSJEČNE OCJENE PERCEPCIJA SADAŠNIH ULOGA KONTROLERA I ULOGA KROZ KOJE BI U BUDUĆNOSTI KONTROLERI ŽELJELI DA IH MENADŽERI PERCIPIRAJU}

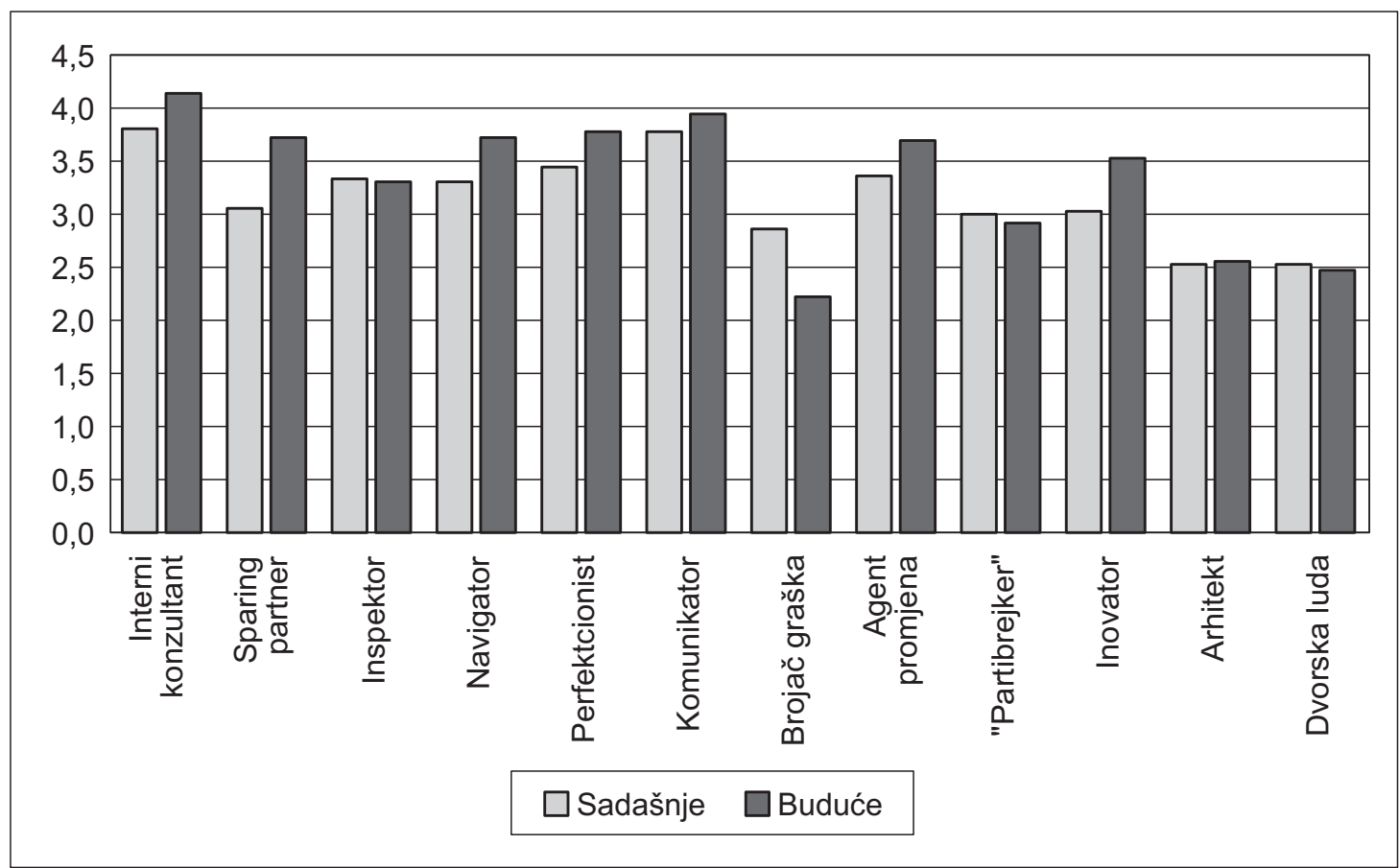

Napomena: raspon vrijednosti Likertove skale od minimalno 1 do maksimalno 5

Izvor: istraživanje autora

Nakon provedenog Shapiro Wilk testa za normalnost podataka u SPSS-u te vizualne inspekcije histograma, utvrđeno je kako prikupljeni ordinalni podaci nisu normalno distribuirani, stoga smo umjesto parametrijskog zavisnog T-testa (engl. Paired T-test), za analizu navedenih uloga i razlika između sadašnje i željene percepcije uloga kako bi kontroleri željeli da ih menadžeri percipiraju, primijenili neparametrijski ekvivalent Wilcoxon test (engl. Wilcoxon signed rank test) koji se može primijeniti i za primjerice usporedbu dva zavisna uzorka istih ispitanika za različite vremenske periode.

U ovom slučaju evaluira se promjena u vremenu, odnosno analizirala se sadašnja i željena percepcija menadžera o ulozi kontrolera u poduzeću, vidljivo u tablicama 4. i 5 . 
Tablica 4 .

\section{WILCOXON SIGNED RANKS TEST - 1. DIO}

\begin{tabular}{|c|c|c|c|c|c|c|}
\hline & $\begin{array}{c}\text { Interni } \\
\text { konzultant } \\
\text { (Pored } \\
\text { funkcije } \\
\text { pružanja } \\
\text { informacija } \\
\text { u obliku } \\
\text { brojeva, } \\
\text { kontroler } \\
\text { obavlja i } \\
\text { savjetodav- } \\
\text { nu funkciju } \\
\text { kao npr. } \\
\text { predla- } \\
\text { ganje ko- } \\
\text { rektivnih } \\
\text { mjera u } \\
\text { budžetu) }\end{array}$ & $\begin{array}{c}\text { Sparing } \\
\text { partner } \\
\text { menad- } \\
\text { žmentu } \\
\text { (Kontroler } \\
\text { obavlja } \\
\text { funkciju } \\
\text { kritičkog } \\
\text { preispitiva- } \\
\text { nja aktiv- } \\
\text { nosti me- } \\
\text { nadžment) }\end{array}$ & $\begin{array}{c}\text { Inspektor } \\
\text { (Kontroler } \\
\text { mora imati } \\
\text { određenu } \\
\text { dozu razvi- } \\
\text { jene emo- } \\
\text { cionalne } \\
\text { inteligenci- } \\
\text { je kako bi } \\
\text { se izbjegle } \\
\text { negativne } \\
\text { posljedice } \\
\text { nadzora } \\
\text { npr. u } \\
\text { slučaju } \\
\text { otkrivanja } \\
\text { greški) }\end{array}$ & $\begin{array}{c}\text { Navigator } \\
\text { (Kontroler } \\
\text { je zadužen } \\
\text { za održa- } \\
\text { vanje kor- } \\
\text { porativne } \\
\text { politike u } \\
\text { skladu sa } \\
\text { zadanim } \\
\text { ciljevima) }\end{array}$ & $\begin{array}{c}\text { Perfekcio- } \\
\text { nist (Kon- } \\
\text { troler koji } \\
\text { je uporan } \\
\text { u raciona- } \\
\text { liziranju i } \\
\text { konstantno } \\
\text { traži i vidi } \\
\text { prostora za } \\
\text { napredak) }\end{array}$ & $\begin{array}{c}\text { Komuni- } \\
\text { kator } \\
\text { (Nagla- } \\
\text { sak je na } \\
\text { odnosu } \\
\text { kontroler- } \\
\text { menadžer. } \\
\text { Kontroler } \\
\text { mora } \\
\text { omogućiti } \\
\text { ključne } \\
\text { podatke i } \\
\text { implikacije } \\
\text { istih na od- } \\
\text { govarajući } \\
\text { način kako } \\
\text { bi postigao } \\
\text { pozitivan } \\
\text { učinak na } \\
\text { akcije me- } \\
\text { nadžera) }\end{array}$ \\
\hline Z & $-3,664^{b}$ & $-4,891^{\mathrm{b}}$ &,$- 344^{c}$ & $-3,758^{b}$ & $-3,124^{b}$ & $-2,238^{\mathrm{b}}$ \\
\hline $\begin{array}{l}\text { Asymp. } \\
\text { Sig. } \\
\text { (2-tailed) }\end{array}$ & ,000 &, 000 & ,731 &, 000 & ,002 & ,025 \\
\hline
\end{tabular}

Napomena 1: b. Bazirano na pozitivnim rangovima. Napomena 2: c. Bazirano na negativnim rangovima.

Napomena 3: Za svaku pojedinu ulogu evaluirala su se pitanja koja se odnose na „U kojoj mjeri Vas najčešće doživljava menadžment Vašeg poduzeća/ organizacije?“ i „Kroz koje uloge i u kojoj mjeri bi ste najviše željeli da Vas menadžer percipira?“

Izvor: istraživanje autora 


\section{Tablica 5 .}

\section{WILCOXON SIGNED RANKS TEST - 2. DIO}

\begin{tabular}{|c|c|c|c|c|c|c|}
\hline & $\begin{array}{c}\text { Brojač } \\
\text { graška } \\
\text { (Ovaj } \\
\text { profil } \\
\text { kontrolera } \\
\text { promatra } \\
\text { sve kroz } \\
\text { brojeve i } \\
\text { njegova } \\
\text { primarna } \\
\text { funkcija je } \\
\text { informa- } \\
\text { tivna) }\end{array}$ & $\begin{array}{c}\text { Agent } \\
\text { promjena } \\
\text { (Zahvalju- } \\
\text { jući njiho- } \\
\text { voj samo- } \\
\text { stalnosti, } \\
\text { kontroler } \\
\text { je u dobroj } \\
\text { poziciji } \\
\text { doprinijeti } \\
\text { prihva- } \\
\text { ćanju } \\
\text { promjena } \\
\text { i njihovom } \\
\text { nadzoru ) }\end{array}$ & $\begin{array}{c}\text { „Parti- } \\
\text { brejker“6 } \\
\text { (Kontroler } \\
\text { ovdje preu- } \\
\text { zima ulogu } \\
\text { filtera u } \\
\text { procesu } \\
\text { planiranja } \\
\text { i budžeti- } \\
\text { ranja i ima } \\
\text { zadatak } \\
\text { imple- } \\
\text { mentiranja } \\
\text { rezova) }\end{array}$ & $\begin{array}{l}\text { Inovator } \\
\text { (Dosada } \\
\text { je ta uloga } \\
\text { bila po- } \\
\text { dređena u } \\
\text { interakciji } \\
\text { kontroler- } \\
\text { menadžer. } \\
\text { Kontroler } \\
\text { preuzima } \\
\text { dio uloga } \\
\text { menadže- } \\
\text { ra) }\end{array}$ & $\begin{array}{l}\text { Arhitekt } \\
\text { (Kontro- } \\
\text { ler nema } \\
\text { slobodu } \\
\text { formirati } \\
\text { aktivnosti } \\
\text { unutar } \\
\text { organiza- } \\
\text { cije) }\end{array}$ & $\begin{array}{c}\text { Dvorska } \\
\text { luda } \\
\text { (Ova uloga } \\
\text { opisuje } \\
\text { činjenicu } \\
\text { da je kon- } \\
\text { troler jedi- } \\
\text { na osoba u } \\
\text { poduzeću } \\
\text { koja može } \\
\text { izraziti } \\
\text { 'bolnu' } \\
\text { istinu bez } \\
\text { straha od } \\
\text { negativnih } \\
\text { reperku- } \\
\text { sija) }\end{array}$ \\
\hline $\mathrm{Z}$ & $-5,092^{\mathrm{c}}$ & $-3,245^{\mathrm{b}}$ &,$- 874^{\mathrm{c}}$ & $-4,358^{b}$ &,$- 278^{\mathrm{b}}$ &,$- 656^{\mathrm{c}}$ \\
\hline $\begin{array}{l}\text { Asymp. } \\
\text { Sig. (2-tai- } \\
\text { led) }\end{array}$ &, 000 &, 001 & ,382 &, 000 & ,781 &, 512 \\
\hline
\end{tabular}

Napomena 1: b. Bazirano na pozitivnim rangovima.

Napomena 2: c. Bazirano na negativnim rangovima.

Napomena 3: Za svaku pojedinu ulogu evaluirala su se pitanja koja se odnose na „U kojoj mjeri Vas najčešće doživljava menadžment Vašeg poduzeća/ organizacije?“i „Kroz koje uloge i u kojoj mjeri bi ste najviše željeli da Vas menadžer percipira?“

Izvor: istraživanje autora

Rezultati Wilcoxon testa ukazuju da su rezultati uloga kroz koje bi u budućnosti kontroleri željeli da ih menadžeri percipiraju statistički signifikantno viši u odnosu na sadašnje percepcije uloge kontrolera od strane menadžera i to kod:

Interni konzultant $\mathrm{Z}=-3,664, \mathrm{p}=0,000$

Sparing partner $Z=-4,891, p=0,000$

Navigator $Z=-3,758, p=0,000$ 
Perfekcionist $\mathrm{Z}=-3,124, \mathrm{p}=0,002$

Komunikator $\mathrm{Z}=--2,238, \mathrm{p}=0,025$

Agent promjena $\mathrm{Z}=--3,245$, $\mathrm{p}=0,001$

Inovator $\mathrm{Z}=-4,358, \mathrm{p}=0,000$

Rezultati Wilcoxon testa ukazuju da su rezultati uloga kroz koje bi u budućnosti kontroleri željeli da ih menadžeri percipiraju statistički signifikantno niži u odnosu na sadašnje percepcije uloge kontrolera od strane menadžera i to kod sljedeće uloge kontrolera u poduzećima:

Brojač graška $\mathrm{Z}=-5,092, \mathrm{p}=0,000$

Analiza ostalih uloga kontrolera (Inspektor $\mathrm{Z}=-0,344, \mathrm{p}=0,731$; „Partibrejker“ $Z=-0,874, p=0,382$; Arhitekt $Z=-0,278, p=0,781$ Dvorska luda $Z=-0656$, $\mathrm{p}=0,512)$ nije ukazala da se rezultati uloga kroz koje bi u budućnosti kontroleri željeli da ih menadžeri percipiraju u odnosu na sadašnje percepcije uloga kontrolera od strane menadžera statistički signifikantno razlikuju.

Procjena porasta značaja uloga internog konzultanta, sparing partnera, navigatora, perfekcionista, komunikatora, agenta promjena i inovatora s jedne strane potvrđuju tezu da je kontroling u Hrvatskoj na razini sparing partnera i internog konzultanta koji u svojoj ulozi nadzornika regulira usklađenost ciljeva s korporativnom politikom u čemu su mu komunikacijske vještine glavni alat u odnosu s menadžerom, a s druge strane ukazuju da je trend razvoja ka business partneru prepoznat od strane kontrolera, dok je uloga brojača graška stvar prošlosti. Procjena najvažnijih uloga u budućnosti odgovaraju procjenama najvažnijih kompetencija čime se dolazi do zaključka da će kontroler i dalje obavljati svoje tradicionalne zadatke, ali s proširenom ulogom.

\section{Kruskal Wallis test i Mann Whitney test}

Naredno smo analizirali razinu uspješnosti poslovanja (mjereno kriterijem dobiti - iznad, ispod ili u razini prosjeka djelatnosti u kojoj poduzeće posluje) i razine percepcije pojedinih uloga kontrolera od strane menadžera, gdje se željelo utvrditi koje uloge kontrolera su označene višim ocjenama u uspješnijim poduzećima (evaluirano prema financijskom kriteriju dobiti). Kako bi se utvrdilo postoje li statistički signifikantne razlike između pojedinih uloga kontrolera i dobiti (iznad, ispod i u prosjeku s djelatnosti u kojoj poduzeće posluje), primijenio se Kruskal-Wallis $\mathrm{H}$ test (engl. Kruskal-Wallis rank test of variance). Rezultat provedenih testova prikazuju se u tablicama 6. i 7. 


\section{Tablica 6.}

KRUSKAL WALLIS TEST - 1 . DIO

\begin{tabular}{|l|c|c|c|c|c|c|}
\hline $\begin{array}{l}\text { U kojoj mjeri Vas } \\
\text { najčešće doživljava } \\
\text { menadžment } \\
\begin{array}{l}\text { Vašeg poduzeća/ } \\
\text { organizacije? }\end{array}\end{array}$ & $\begin{array}{c}\text { Interni } \\
\text { konzul- } \\
\text { tant }\end{array}$ & $\begin{array}{c}\text { Sparing } \\
\text { partner } \\
\text { mena- } \\
\text { džmentu }\end{array}$ & $\begin{array}{c}\text { Inspek- } \\
\text { tor }\end{array}$ & $\begin{array}{c}\text { Naviga- } \\
\text { tor }\end{array}$ & $\begin{array}{c}\text { Perfek- } \\
\text { cionist }\end{array}$ & $\begin{array}{c}\text { Komu- } \\
\text { nikator }\end{array}$ \\
\hline Chi-Square & 4,12 & 10,168 & 1,809 & 4,18 & 4,544 & 0,364 \\
\hline df & 2 & 2 & 2 & 2 & 2 & 2 \\
\hline Asymp. Sig. & 0,127 & 0,006 & 0,405 & 0,124 & 0,103 & 0,834 \\
\hline
\end{tabular}

Grupirajuća varijabla: Prema Vašem viđenju, Vaša organizacija/ poduzeće je iznad, ispod ili u razini prosjeka industrije u kojoj posluje? Za procjenu možete koristiti kriterij dobiti.

Izvor: istraživanje autora

\section{Tablica 7.}

KRUSKAL WALLIS TEST -2 . DIO

\begin{tabular}{|c|c|c|c|c|c|c|}
\hline $\begin{array}{l}\text { U kojoj mjeri Vas } \\
\text { najčešće doživljava } \\
\text { menadžment } \\
\text { Vašeg poduzeća/ } \\
\text { organizacije? }\end{array}$ & $\begin{array}{l}\text { Brojač } \\
\text { graška }\end{array}$ & $\begin{array}{c}\text { Agent } \\
\text { promje- } \\
\text { na }\end{array}$ & $\begin{array}{l}\text {,Parti- } \\
\text { brejker" }\end{array}$ & Inovator & Arhitekt & $\begin{array}{c}\text { Dvorska } \\
\text { luda }\end{array}$ \\
\hline Chi-Square & 1,892 & 6,879 & 2,711 & 0,74 & 1,263 & 4,387 \\
\hline $\mathrm{df}$ & 2 & 2 & 2 & 2 & 2 & 2 \\
\hline Asymp. Sig. & 0,388 & 0,032 & 0,258 & 0,691 & 0,532 & 0,112 \\
\hline
\end{tabular}

Grupirajuća varijabla: Prema Vašem viđenju, Vaša organizacija/ poduzeće je iznad, ispod ili u razini prosjeka industrije u kojoj posluje? Za procjenu možete koristiti kriterij dobiti.

Izvor: istraživanje autora

Rezultati Kruskal Wallis $\mathrm{H}$ testa ukazuju na postojanje statistički signifikantnih razlika između skupina ispitanika koji su označili poslovanje poduzeća uspješnijim (iznad, ispod ili u razini prosjeka djelatnosti u kojoj poduzeće posluje) i višom ocjenom kod uloga kontrolera: Sparing partner $(\mathrm{H}(2)=10,168, \mathrm{p}=0,006) \mathrm{i}$ Agent promjena $(\mathrm{H}(2)=6,879, \mathrm{p}=0,032)$. 
S obzirom da u analiziranim slučajevima Kruskal-Wallis test ima 3 klasifikacijske skupine uspješnosti poslovanja (iznad, ispod ili u razini prosjeka djelatnosti u kojoj poduzeće posluje), kako bi se utvrdilo između kojih točno skupina postoje statistički signifikantne razlike s obzirom na ocjene uloga kontrolera, primijenio se Mann-Whitney U Test. Primjenom navedenog testa za identificiranje razlika uloga između skupina kod uloge Sparing partnera, statistički signifikantne razlike postoje između iznad prosječnih i poduzeća koja posluju u razini prosjeka djelatnosti. Nadalje, druga prethodno Kruskal-Wallis testom identificirana statistički signifikantna razlika kod uloge Agenta promjena se također primjenom MannWhitney testa analizirala kako bi se utvrdilo između kojih točno skupina (iznad, ispod ili u razini prosjeka djelatnosti u kojoj poduzeće posluje) postoje statistički signifikantne razlike s obzirom na ocjene uloga kontrolera. Pritom su identificirane statistički signifikantne razlike između iznad prosječnih i u poduzeća koja posluju u razini prosjeka djelatnosti.

Rezultati navedenih testova prikazuju da je uspješnost poslovanja poduzeća korelirana s ulogama kontrolera kao sparing partnera i agenta promjena, dvjema ulogama koje su komplementarne. Uloga sparing partnera podrazumijeva analitičku i komercijalnu sposobnost (eng. commercial acumen), a agent promjena vještinu pregovaranja, mijenjanja statusa quo i utjecanja čime se može zaključiti da uspješnija poduzeća u Hrvatskoj dozvoljavaju kontrolerima veći stupanj slobode i djelovanja, ali i da sami kontroleri posjeduju spektar znanja i vještina koji im omogućava takvu slobodu. Poticanje uloga sparing partnera i agenta promjena u uspješnijim poduzećima svakako znači da su poduzeća u Hrvatskoj prepoznala koliko kontroleri značajno više mogu doprinijeti poslovanju ako im se dodijele višeg ranga uloge te se može zaključiti da se razvoj kontrolinga u uspješnijim poduzećima u Hrvatskoj kreće ka business partneringu.

Nadalje, istraživanjem se nastojalo dobiti uvid u značaj dodatnih čimbenika koji mogu utjecati na kompetencije i uloge kontrolera (Grafikon 3. Prosječne ocjene čimbenika koji mogu utjecati na kompetencije i uloge kontrolera). Kontroleri su ocijenili prosječnim ocjenama sljedeće tvrdnje, vidljivo u Grafikonu 3. 


\section{Grafikon 3.}

\section{PROSJEČNE OCJENE ČIMBENIKA KOJI MOGU UTJECATI NA KOMPETENCIJE I ULOGE KONTROLERA}

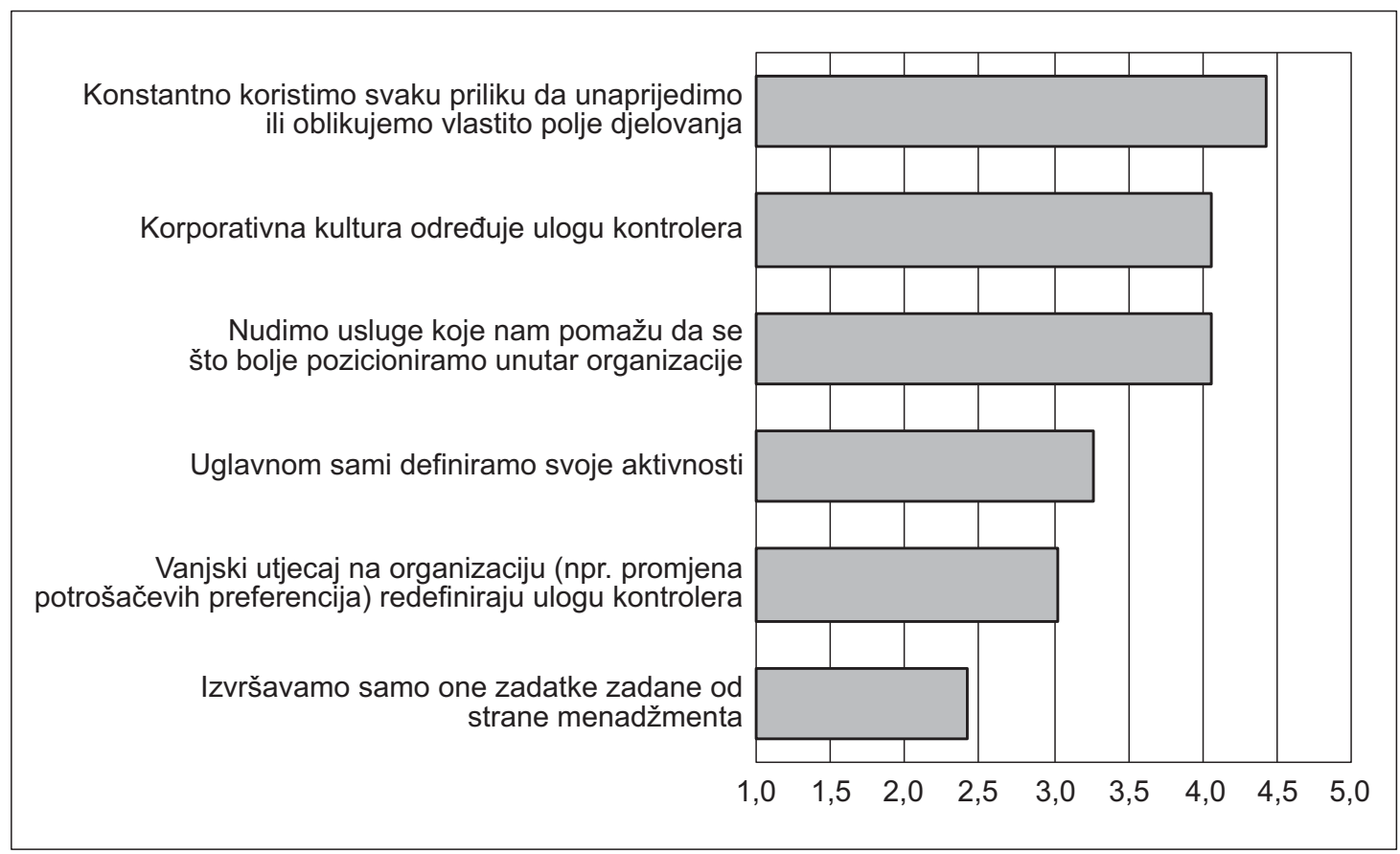

Napomena: raspon vrijednosti Likertove skale od minimalno 1 do maksimalno 5

Izvor: istraživanje autora

Sukladno literaturi, kao najveći utjecaj na razvoj kontrolera ističe se proaktivnost samog kontrolera i njegova želja da unaprijedi svoje područje djelovanja i izvršava zadatke izvan okvira menadžerovih zahtjeva. No, koliko će moći razviti svoju ulogu ovisi o slobodi koju mu menadžer daje za što prema rezultatima istraživanja možemo utvrditi da kontroleri uglavnom imaju slobodu definirati sami svoje aktivnosti što je važan preduvjet za business partnering. Korporativna kultura kao dio mikro okruženja ima veći utjecaj na kompetencije i uloge kontrolera od vanjskih utjecaja. Također, percepcija kontrolera da posjeduju vještine koje im pomažu da se što bolje pozicioniraju unutar organizacije ukazuje da su kontroleri spremni za preuzimanje veće odgovornosti i aktivnosti koje stvaraju vrijednost u odnosu na tzv. scorekeeping aktivnosti koje se bave prošlim događajima te kao takve ne stvaraju novu vrijednost za poduzeće. 


\section{Komparacija potrebnih kompetencija i uloga kontrolera putem provedenih empirijskih istraživanja u Hrvatskoj i Njemačkoj}

Budući da je anketni upitnik oblikovan na temelju već navedenog WHU Controller Panel istraživanja objavljenog od strane vodećih njemačkih autoriteta na području kontrolinga dr. U. Schäffera i dr. J. Webera, provedena je i usporedba hrvatskih i njemačkih poduzeća kako bi se utvrdile potencijalne razlike/sličnosti u potrebnim kompetencijama i ulozi kontrolera u poduzeću. Pretpostavilo se kako ne postoje značajne razlike u značajkama kontrolera u velikim i srednjim poduzećima u Hrvatskoj i Njemačkoj.

Za utvrđivanje potrebnih kompetencija kontrolera, Weber i Schäffer proveli su istraživanje na velikim i srednjim poduzećima 2011. godine. Na pitanje koje su najvažnije vještine koje bi kontroler trebao posjedovati, i njemački i hrvatski kontroleri ističu sposobnost kritičkog preispitivanja i prepoznavanja potencijalnih, budućih problema, poslovni know-how i vještinu korištenja kontrolerskih alata. Dok njemački kontroleri $\mathrm{k}$ tome dodaju još i komunikacijske vještine (na drugom mjestu), odlučnost i sposobnost iskorištavanja i prenošenja specifičnih znanja, hrvatski ističu nepristranost (na drugom mjestu), računovodstveni know-how i usmjerenost timskom radu (Tablica 8. Lista najvažnijih kompetencija koje mora posjedovati kontroler u hrvatskim i njemačkim poduzećima). Odgovori se većinom podudaraju iako njemački kontroleri više ističu 'meke vještine' poput komunikacijskih i odlučnosti, a hrvatski kontroleri uz nepristranost i dalje smatraju da je računovodstvo conditio sine qua non. Zaključno, oba skupa odgovora potvrđuju da je kontrolerova odgovornost ona sparing partnera koji posjeduje poslovno znanje i zna to isto i iskoristiti.

Njemački kontroleri su procijenili da će sposobnost kritičkog preispitivanja i prepoznavanja potencijalnih, budućih problema, komunikacijske vještine i uvjeravanje dobiti na važnosti. Hrvatski kontroleri na prvo mjesto također stavljaju istu vještinu kao i njemački, nakon koje slijede IT know-how te vještina kontrolerskih alata. Hrvatski kontroleri vežu budućnost kontrolera uz sparing ulogu uz IT podršku. 
Tablica 8 .

LISTA NAJVAŽNIJIH KOMPETENCIJA KOJE MORA POSJEDOVATI KONTROLER U HRVATSKIM I NJEMAČKIM PODUZEĆIMA

\begin{tabular}{|c|c|c|}
\hline & Hrvatska & Njemačka \\
\hline RANG & \multicolumn{2}{|c|}{ SPOSOBNOSTI } \\
\hline 1. & $\begin{array}{l}\text { sposobnost kritičkog preispitivanja i } \\
\text { prepoznavanja potencijalnih, budućih } \\
\text { problema }\end{array}$ & $\begin{array}{l}\text { sposobnost kritičkog preispitivanja i } \\
\text { prepoznavanja potencijalnih, budućih } \\
\text { problema }\end{array}$ \\
\hline 2. & Nepristranost & Komunikacijske vještine \\
\hline 3. & Poslovni know-how & Poslovni know-how \\
\hline 4. & Računovodstveni know-how & Vještina korištenja kontrolerskih alata \\
\hline 5. & Vještina korištenja kontrolerskih alata & Odlučnost \\
\hline 6. & Usmjerenost timskom radu & $\begin{array}{l}\text { Sposobnost iskorištavanja i prenošenja } \\
\text { specifičnih znanja }\end{array}$ \\
\hline
\end{tabular}

Izvor: usporedba istraživanja autora sa istraživanjem Schäffer, U., Weber, J. (2015.): ControllingTrends\&Benchmarks, IMC, Vallendar, str. 135.

Istraživanje uloge kontrolera u poduzeću su Weber i Schäffer proveli 2010. godine. Na pitanje kroz koju ulogu ih najčešće doživljava menadžment, njemački i hrvatski kontroleri na prvo mjesto stavljaju ulogu internog konzultanta. Njemački dodaju i ulogu sparing partnera (tj. ekonomske savjesti) i inspektora, dok hrvatski komunikatora i perfekcionista. Najmanje ih se doživljava kao dvorske lude ili arhitekte. Postoji visoka podudarnost $\mathrm{u}$ odgovorima jer sparing partner $\mathrm{i}$ jest $\mathrm{u}$ jednu ruku perfekcionist, on preispituje i izaziva menadžera na bolju performansu, a inspektor jest onaj koji treba posjedovati komunikacijske vještine kako bi izbjegao negativne posljedice nadzora tj. inspekcije. Sljedeće pitanje je bilo kroz koju ulogu bi najviše htjeli da ih menadžment percipira (Tablica 9. Lista uloga kroz koje bi kontroleri najviše htjeli da ih menadžment percipira u hrvatskim i njemačkim poduzećima). Odgovori se podudaraju, interni konzultant i uloga sparing partnera su na prva dva mjesta i kod njemačkih i kod hrvatskih kontrolera. Navedeno dokazuje kako bi kontroleri htjeli veću ulogu sparing partnera ali bi htjeli i zadržati distancu koju uživaju kao interni konzultanti. Brojač graška je i jednima i drugima najmanje poželjna uloga jer to i predstavlja najniži razvojni oblik kontrolera. 
D. LABAŠ, M. RAJSMAN: Istraživanje uloge i perspektive razvoja kontrolera kao poslovnog partnera menadžmenta EKONOMSKI PREGLED, 71 (3) 239-270 (2020)

Tablica 9.

\section{LISTA ULOGA KROZ KOJE BI KONTROLERI NAJVIŠE HTJELI DA IH MENADŽMENT PERCIPIRA U HRVATSKIM I NJEMAČKIM PODUZEĆIMA}

\begin{tabular}{|c|c|c|}
\hline & Hrvatska & Njemačka \\
\hline RANG & \multicolumn{2}{|c|}{ ULOGE } \\
\hline 1. & Interni konzultant & Interni konzultant \\
\hline 2. & Sparing partner & Sparing partner \\
\hline 3. & Komunikator & Navigator \\
\hline 4. & Perfekcionist & Komunikator \\
\hline 5. & Navigator & Agent promjena \\
\hline
\end{tabular}

Izvor: obrada autorice, usporedba vlastitog istraživanja sa istraživanjem Schäffer, U., Weber, J. (2015.): Controlling-Trends\&Benchmarks, IMC, Vallendar, str. 143.

\section{Zaključna razmatranja}

Poslovni partner u svjetskoj poslovnoj praksi predstavlja evolucijski, na višu razinu prijelaz za kontrolera. Uz svoj tradicionalni know-how, kontroler je proširio lepezu svojih sposobnosti i mogućnosti i nastavlja preuzimati znanja koja ga po tom istom kriteriju ne razlikuju od menadžera. No, ipak kontrolerova uloga uživa određenu neovisnost i manju odgovornost u odnosu na menadžera. Pitanje je, s kolikim rasponom zadataka i odgovornosti kontroler prestaje biti kontroler, a postaje poslovni partner ili čak konkurent menadžeru? S druge strane, nadograđivanjem uloge kontrolinga nadograđuje se i znanje menadžmenta što dovodi do pitanja hoće li kontroler u budućnosti postati nepotreban, a menadžer postati sam sebi kontroler?

Nadalje, literatura navodi da business partnering nije kraj tradicionalnoj ulozi kontrolera te da će te aktivnosti opstati kao svojevrsna higijena podupirući business partnering u stvaranju vrijednosti za poslovanje. No, razvoj komplementarnih IT rješenja iako još uvijek nisu u potpunosti implementirana, predstavljaju realnu prijetnju takvoj ulozi kontrolera. Edukacija i razvoj u napredniji oblik postaje neminovan uvjet opstanka kontrolera.

Uzimajući u obzir pretpostavku da će kontroler opstati u svom obliku ali s proširenom ulogom, obnašajući istovremeno ulogu nadzornika i poslovnog partnera, dolazi do tzv. dualne odgovornosti gdje kontroler mora birati između vlastite 
samostalnosti ili lojalnosti menadžeru. Takva dualna odgovornost rezultira konfliktom koji će biti izraženiji što su više kontroleri uključeni u proces odlučivanja. Zasada se sa sigurnošću može zaključiti da adaptacija kontrolera u poslovnog partnera ima dvojako značenje s još uvijek nedovoljno istraženim posljedicama.

Prema provedenom istraživanju, uloga kontrolera u srednjim i velikim privatnim poduzećima na području Republike Hrvatske etablirana je kao internog konzultanta i komunikatora s time da uspješnija poduzeća daju kontrolerima proaktivnije uloge poput sparing partnera i agenta promjena. Kontroleri konstantno koriste svaku priliku da unaprijede svoje područje djelovanja, što je znak razvoja uloge kontrolera, no s protokom vremena i daljnjim razvojem tehnologije bit će moguće uvidjeti kreće li se ka poslovnom partneru.

Komparativna analiza njemačkih i hrvatskih kontrolera pokazala je visoku podudarnost stavova u području potrebnih kompetencija i uloge kontrolera što vodi do zaključka da se kontroling u Hrvatskoj razvio na razini europskih standarda.

Globalno, uz povećanu kompleksnost vanjskog i unutarnjeg okruženja, razvoj i implementaciju IT sustava, trend preuzimanja veće uloge kontrolera sve više je prisutan, no s ambivalentnim ishodom.

Znanstveni doprinos ovoga istraživanja odlikuje se unaprjeđenjem postojećih spoznaja iz aktualne tematike razvoja uloga kontrolinga. Doprinos praksi ogleda se u postavljanju smjernica za kontrolere i menadžere na području Hrvatske za potencijalni razvoj business partneringa ili barem sagledavanje opcije proširenja uloge kontrolera kao aktivnijeg dionika.

\section{Ograničenja rada}

Provedeno presječno istraživanje predstavlja glavno ograničenje rada budući da predstavlja trenutno stanje kompetencija i uloga, gdje bi za detaljniji uvid u trendove bilo poželjno provesti longitudinalno istraživanje. Sastavljeni upitnik također predstavlja svojevrsno ograničenje s obzirom da zbog opsega istog nisu sva pitanja mogla biti uključena, kao ni eventualne ostale funkcije kontrolera, a koje bi detaljnije pružile uvid u status kontrolera u hrvatskim poduzećima. Primjenom metode dubinskih intervjua dobio bi se kompletniji uvid u status kontrolera u hrvatskim poduzećima i tendencija razvoja ka poslovnom partneru.

Uz navedeno, rezultati istraživanja temelje se na subjektivnom mišljenju i procjenama pojedinaca koji su ispunjavali anketni upitnik te postoji mogućnost da prikupljeni rezultati odstupaju od realne slike uloge kontrolera u hrvatskim poduzećima. 


\section{Smjerovi budućih mogućih istraživanja}

U budućim istraživanjima predlaže se istražiti stavove junior kontrolera, te utvrditi razlike između direktora kontrolinga i juniora u kontrolingu u percepcijama uloga kontrolera. Također predlaže se istraživanje percepcija menadžera o ulogama kontrolera, budući da su upravo oni jedan od ključnih faktora oblikovanja uloge kontrolera. Nadalje, buduće longitudinalne studije bi mogle promatrati transformacije uloga kontrolera u poduzećima koja posluju u Hrvatskoj. Također, moglo bi se istraživati razlike između javnog i privatnog sektora u vidu uloga kontrolera, kao i razlike među ulogama između podružnica multinacionalnih poduzeća i domaćih poduzeća. Potencijalan smjer istraživanja bi mogao biti i istraživanje postojeće ponude edukacijskih i obrazovnih programa i utjecaja na formiranje uloga kontrolera u poduzećima, kao i kako bi novi edukacijski programi s obzirom na evoluirajuće uloge kontrolera trebali biti koncipirani. Dodatno, potencijalan smjer istraživanja bi mogao biti komparativna analiza hrvatskih, njemačkih i američkih poduzeća.

\section{Literatura}

1. Byrne, S. i Pierce, B. (2007). Towards a More Comprehensive Understanding of the Roles of Management Accountants. European Accounting Review, 16(3), 469-498. Dostupno na https://ssrn.com/abstract=991378

2. Burns, J., Warren, L. i Oliveira, J. (2014). Business Partnering: Is It All That Good? Controlling \& Management Review, 58(2), 36 - 41. DOI: https://doi. org/10.1365/s12176-014-0907-6

3. Clinton, B.D. i White, L. R.(2012). The Role of the Management Accountant: 2003-2012. Management Accounting Quarterly, 14( 1), 40 - 74. Dostupno na https://www.imanet.org/-/media/104eed2f3f3b4713a5f47e64f312192b.ashx

4. CPA Australia Ltd. (2016). Finance Business Partnering: Deconstructing elements for success. 1 - 17. Dostupno na https://www.cpaaustralia.com.au/ / media/corporate/allfiles/document/training/deconstructing-elements-forsuccess.pdf

5. Deloitte (2012). Changing the Focus: Finance Business Partnering. Finance Transformed. 1 - 12. Preuzeto s https://www2.deloitte.com/content/dam/Deloitte/uk/Documents/finance-transformation/deloitte-uk-finance-businesspartnering.pdf 
6. Forbes Insights (2016). The Transformative Controller - Adding Value, Insight and a Bridge to the Future, 1 - 20. Dostupno na https://home.kpmg/ content/dam/kpmg/pdf/2016/05/forbes-transformative-controller.pdf

7. Forsaith, D., Tilt, C. i Xydias-Lobo, M. (2004). The Future of Management Accountant: A South Australian Perspective. JAMAR, 2.(1), 1 - 20. Dostupno na https://www.researchgate.net/publication/239923424_THE_FUTURE_ OF_MANAGEMENT_ACCOUNTING_A_SOUTH_AUSTRALIAN_ PERSPECTIVE

8. Gänßlen, S., Losbichler, H., Niedermayr, R., Rieder, L., Schäffer, U. i Weber, J. (2012). TEMELJNA NAČELA KONTROLINGA prema Internationaler Controller Verein (ICV) i International Group of Controlling (IGC). $1-8$. Dostupno na: https://www.icv-controlling.com/fileadmin/Verein/Verein Dateien/Grundsatzpapier/Grundsatzpapier_KROATISCH.pdf

9. Goretzki, L., Lukka, K. i Messner, M. (2018). Controller's use of informational tactics. Accounting and Business Research, 48(6), 700 - 726. DOI: 10.1080/00014788.2017.1407627

10. Gupta, S., Copleston, R. i Malhotra, R. (2016). Finance as a strategic business partner: four transformation imperatives. 4. Hfs Research and the Genpact Research Institute, „Finance in the Digital Age“. 1 - 8. Dostupno na https:// www.genpact.com/downloadable-content/insight/finance-as-a-strategicbusiness-partner-four-transformation-imperatives.pdf

11. Hartman, F.G.H. i Maas, V.S. (2011). The effects of uncertainty on the roles of controllers and budgets: an exploratory study. Accounting and Business Research, 41(5), 439-458. DOI: 10.1080/00014788.2011.597656

12. Henke, N., Levine, J. i Mclnerney, P. (2018). You Don't Have to be a Data Scientist to Fill This Must-Have Analytics Role. Harvard Business Review, February 05. Dostupno na https://hbr.org/2018/02/you-dont-have-to-be-adata-scientist-to-fill-this-must-have-analytics-role

13. Hyvönen, T., Järvinen, J. i Pellinen, J. (2015). Dynamics of Creating a New Role for Business Controllers. Nordic Journal of Business, 64(1), 21 - 39. Dostupno na http://njb.fi/wp-content/uploads/2015/06/Hyv\%C3\%B6nen_etal.pdf

14. Järvenpää, M. (2007). Making Business Partners: A Case Study on How Management Accounting Culture Was Changed. European Accounting Review, 16(1), 99 - 142. Dostupno na https://doi.org/10.1080/09638180701265903

15. Laval, V. (2015). Impact of Recent Megatrends on the Controlling Role Model. Procedia Economics and Finance 27, 54 - 63. DOI: 10.1016/S22125671(15)00971-5.

16. Lawson, R. (2016). How Controllers Become Business Partners. Strategic Finance, 7, 25 - 31. Dostupno na https://sfmagazine.com/post-entry/july2016-how-controllers-become-business-partners/ 
17. Lawson, R. (2018). Management Accounting Competencies: Fit for Purpose in a Digital Age? Institute of Management Accountants, 1 - 19. Dostupno na https://www.imanet.org/insights-and-trends/the-future-of-managementaccounting/management-accounting-competencies---fit-for-purpose-in-adigital-age?ssopc $=1$

18. PricewaterhouseCoopers (2009). Adding Up or Adding Value? Making business partnering work. 1 - 9. Dostupno na https://www.pwc.co.uk/assets/pdf/ adding-up-or-adding-value.pdf

19. PricewaterhouseCoopers. (2017a). Finance as Business Partner „Adding up or adding value" Research: The most important aspects of being a good Business Partner. 1 - 24. Dostupno na https://www.pwc.nl/nl/assets/documents/ pwc-finance-as-business-partner-adding-up-or-adding-value-2017.pdf

20. PricewaterhouseCoopers. (2017b). Stepping up: How finance functions are transforming to drive business results. Finance Effectiveness Benchmark Report 2017. 1 - 68. Dostupno na https://www.pwc.at/de/publikationen/verschiedenes/pwc-finance-effectiveness-benchmark-report-2017.pdf

21. Quinn, M. (2014). The Elusive Business Partner Controller. Controlling \& Management Review, 58(2), 22 - 27. Dostupno na https://doi.org/10.1365/ s12176-014-0905-8

22. Robert Half Management Resources (2012). Business Partnering: Optimising corporate performance. An independent report on the expanding role of finance teams. 1 - 21. Preuzeto s https://www.roberthalf.co.uk/expertise-advice/research-insights/reports-guides/executive-research/business-partnering-report

23. Schäffer, U. (2017). „Man muss die Maschine einfach mal machen lassen“. In dialog with Stefan Schnell. Controlling \& Management Review, 61(9), 24-31. Dostupno na https://www.whu-on-controlling.com/fileadmin/data_ whu-on-controlling/Publikationen/Interviews/WHU-on-Controlling-CMRInterview-Schaeffer-Schnell-2017.pdf

24. Schäffer, U., Losbichler, H., Gaensslen, S. i Rieder, L. (2013). The Essence of Controlling - the Perspective of the Internationaler Controller Verein (ICV) and the International Group of Controlling (IGC). Journal of Management Control, 23(4), 311 - 317. DOI 10.1007/s00187-013-0168-0

25. Schäffer, U. i Weber, J. (2015a.). Controlling-Trends\&Benchmarks. Vallendar: WHU - Otto Beisheim School of Management.

26. Scäffer, U. i Weber, J. (2015b) The Journey from "Master of Numbers" to Business Partner. WHU - Otto Beisheim School of Management. 1 - 4. Dostupno na https://www.whu-on-controlling.com/en/latest-thinking/business-partner/ 
27. Scäffer, U., Weber, J. (2015c) Business Partnering with Managers and Experts. WHU - Otto Beisheim School of Management. 1 - 3. Dostupno na https://www.whu-on-controlling.com/en/latest-thinking/business-partner/

28. Vaivio, J. (2006). The Business Controller, Non-Financial Measurement and Tacit Knowledge. Liiketaloudellinen aikakauskirja, 55(2), $194-212$. Dostupno na http://njb.fi/wp-content/uploads/2015/05/lta_2006_02_a3.pdf

29. Waelter, A., Kaplan, B., Gibson, A.B. i Krumwiede, K. (2018). Stepping Outside the Box: Elevating the Role of the Controller. The Association of Accountants and Financial Professionals in Business, 1 - 18. Dostupno na https://www.imanet.org/insights-and-trends/business-leadership-and-ethics/ stepping-outside-the-box-elevating-the-role-of-the-controller?ssopc $=1$

30. Weber, J. (2018). „Robotics wird so selbstverständlich sein wie Elektrizität“. In dialog with Marcus Kuhnert. Controlling \& Management Review 62(8), 24-29. Dostupno na: file:///C:/Users/dlabas/Downloads/CMR-2018-8-Juergen-Weber-Markus-Kuhnert-Im-Dialog-Merck-Robotics.pdf

31. Wolf, S., Weißenberger, B. E., Wehner, M. C. i Kabst, R. (2015). Controllers as business partners in managerial decision-making: Attitude, Subjective Norm, and Internal Improvements. Journal of Accounting \& Organizational Change, 11(1), 24 - 26. DOI: 10.1108/JAOC-10-2012-0100

32. Zastrow, F. (2016). Financial controlling's top 3 trends. LucaNet. 1 - 19. Dostupno na https://www.lucanet.com/en/info-center/whitepaper/financialcontrolling-s-top-3-trends/

\section{RESEARCHING THE ROLE AND DEVELEOPMENT PERSPECTIVE OF A CONTROLLER AS A BUSINESS PARTNER OF MANAGEMENT}

\section{Summary}

Megatrends such as increasing business complexity and volatility, internationalization and greater demand for transparency, have caused changes in management expectations of controller's roles. A significant number of existing studies had emphasized the changes towards a more proactive role of a controller as an equal business partner in managerial strategic decision-making process. The stated trend was intensified by the development of digitalization and IT solutions, which will enable additional value, and unburden controllers from routine tasks. Such development should accordingly create a new role for controllers. So far, the use of a new controller's role in business practice is inadequately researched, along with the implications of consequences for controllers, which should simultaneously cooperate with and correct the management. This paper explores the development perspective of a controller as a business partner. Accordingly, empirical research of controller's roles was conducted in Croatian based firms, with an aim to discover which roles controllers predominantly take on, and whether they are moving in the direction of a more proactive future roles.

Key words: business partner, new roles of controllers, redefining the controllers roles. development of digitalizationa and IT solutions 